\title{
THE ANNALS
}

AND

\section{MAGAZINE OF NATURAL HISTORY.}

\author{
[THIRD SERIES.]
}

No. 23. NOVEMBER 1859.

XXXIII.-On the Reproduction of the Bark-Lice (Chermes, \&c.); a further Contribution to the Knowledge of Parthenogenesis. By Rudolph Leuckart*.

\section{[With a Plate.]}

IN my small work upon the alternation of generations and parthenogenesis in Insects (Frankfort, 1858), I have proved that a spontaneous evolution of the eggs takes place in the Coccina and allied animals. Among the latter I particularly cited the genus Chermes, which is usually referred to the Aphides by entomologists, and may indeed approach most closely to those animals on the whole, although in many respects it constitutes the transition to the Coccina.

What I was able to state then with regard to Chermes related, however, exclusively to the wingless generation of these soealled Bark-lice. I had ascertained that all the individuals of this generation were of the female sex, and that they laid eggs capable of evolution without the cooperation of males. The winged individuals had not at that time been investigated, with the exception of a few specimens of $C$. Laricis, which were also found to be virgin females.

Hoping to be able to extend my observations to the latter also, and thus to obtain an insight into the entire history of the reproduction of these remarkable creatures, my statements with regard to Chermes in general were rather short and aphoristic, forming to a certain extent only an appendix to the observations upon the Coccina and the Aphides with viviparous generations.

As I have paid much attention to the animals in question in the course of the past summer, and, in my opinion, have arrived

* Translated from the 'Archiv für Naturgeschichte,' 1859, p. 209, by W. S. Dallas, F.L.S., Keeper of the York Museum.

Ann. \& Mag. N. Hist. Ser. 3. Vol. iv. 
at a pretty good conclusion with regard to them, I have thought it the less advisable to keep back my observations, as they not only furnish us with a new and interesting contribution to the knowledge of Parthenogenesis, but also throw some light upon many other long-known peculiarities in the reproduction of insects.

But, before I commence with the special exposition of my investigations, a few words on the mode of life of the animals may not be out of place, so far as this may be ascertained by mere external observation, especially as it is fully described from actual observation in the works of De Geer (Mémoires, tome iii. pp. 66-84, tab. 8), Kaltenbach (Monographie der Familien der Pflanzenläuse, 1843, pp. 193-206), and Ratzeburg (Forstinsekten, 1847, Theil iii. pp. 195-205, tab. 12, 13)*.

We treat in the first place of the common Fir-louse (C. Abietis, Linn.), which is divided into two species by both the lastmentioned authors, namely $C$. Abietis, Kalt. =C. viridis, Ratzeb., and $C$. strobilobius, Kalt. $=C$. coccineus, Ratzeb. The distinction of these two species, which, however, may be justified by the size and position of their galls, is of no consequence to us ; for both forms, which are very nearly allied even externally, agree so closely biologically and anatomically, that I have looked in vain for a distinction between them. (I will not, however, omit to mention, in passing, that my investigations were made prineipally upon the first of these two species or varieties.)

By the investigations of the above-mentioned entomologists it is satisfactorily established that the Fir-louse passes the winter in the wingless state, in the form of a plump insect not larger than a grain of sand, beneath the protective covering of a whitish woolly coat, at the base of the scaly young buds of the Fir. It is only in the following spring (April) that the little animal begins to grow. It is then always found in its old place, immoveable; and on closer examination its rostrum is observed to be inserted deeply into the axis of the awakening bud. That our insect pierces the individual leaves, as asserted by Kaltenbach and also by De Geer, is incorrect; I have never seen it elsewhere than in the above situation, and might even suppose that it remains in this position until its death, without ever changing the place of insertion of its rostrum to any extent. Close above the perforation, even at this time, before the evolution of the buds, the axis of the young shoot, with the leaves attached to it, begins to swell; thus commences the first founda-

* Hartig's memoir (Germar's Zeitschrift für die Entomol. iii. p. 366) is not in my possession at the moment; and I pass it over with the less reluctance, as his statements are frequently inaceurate and erroneous, - at least as regards $C$. Abietis. 
tion of those remarkable pine-apple-like galls which, as we shall see hereafter, serve as the dwelling-place of the second generation of our animal.

After the Fir-louse, constantly increasing in size, has repeatedly changed its skin in the course of the next three weeks, and at the same time renewed its woolly covering (Kaltenbach), which, as is well known, pushes out gradually from the skin of the body in single threads, as a secretion (wax?), the oviposition commences, still before the evolution of the young shoot. The eggs are attached to the bud behind the mother by means of a short style, and are usually also clothed at the same time with cast woolly threads; they gradually accumulate here in such quantities, that as many as 200 of them may not unfrequently be counted* towards the close of the oviposition, which, indeed, does not arrive until the death of the mother, when the oldest eggs are already hatched.

The exclusion of the young takes place in the latter half of May, soon after the young shoot has broken out through the enveloping scales with its axis, which is abbreviated and thickened at its lower end. The young brood immediately quits its birthplace, and moves forward in a mass, to find a new dwelling between the closely approximated swelled leaves of the shortened shoot. Here the young brood completes what its mother had begun. Hundreds of suckers sink into the juicy leaves; and under the influence of this continual irritation the leaves close up to form that globular or oval head $†$ which we have already mentioned as the dwelling-place of the second generation. An amalgamation of the leaves, such as has been supposed by some, does not take place, although their outer margins are closely applied to each other. Tolerably spacious cell-like cavities also remain between the leaves in the interior; and each of these is almost constantly inhabited by several young plant-lice, sometimes a dozen together.

These animals of the second generation are more slender and mobile than the individuals which have lived through the winter, from which we started in our investigations; they also appear to be by no means so continually attached by the rostrum. At least, on opening a cell, a number of animals living free in the interior are almost always found, whilst the rest adhere to the walls. These animals, like their free parents, clothe themselves

* Kaltenbach is far below the mark when he estimates the number of eggs deposited by a single mother "at thirty or more."

$\uparrow$ Very frequently, however, these galls are attached excentrically upon the shoot, and are then, of course, less regularly rounded. Perhaps in such cases the insect has not penetrated with its rostrum quite to the middle of the abbreviated axis. 
with a woolly down, but this is very much shorter. Like their parents, they are subject to a repeated change of skin as the size of their bodies increases, but they do not by this means perceptibly alter in their appearance. Towards the end of July these larvæ become converted into pupæ; they then present wing-cases, and are all attached, almost immoveably, with the legs retracted, by means of the rostrum, to the wall of the cell. In about a fortnight the metamorphosis is complete; the cells of the galls open, by the separation of the leaves, which gradually dry; and from the gaping fissures the crowd of pupæ, which have again become capable of motion, escape, usually in the sunshine. These ascend the leaves in the vicinity, cling firmly with their legs, and then, by another change of skin, become converted in a few minutes into winged Aphis-like creatures, which remain sitting close together for a time on the leaves, and then disperse in all directions.

In the course of a few days, single individuals of these Aphides are found dead, with their wings spread out in a rooflike form, here and there upon the leaves, and beneath them a small aggregation of pedunculated eggs, partly enveloped in the woolly hairs, adhering to the abdomen of the mother. The young, which escape from the eggs in the course of a few weeks, disperse themselves, and seek the developed buds in the vicinity, usually singly, seldom two or more together; upon these, as above stated, they hibernate, and in the next year, with a more abundant nourishment, produce a new progeny.

Our present knowledge of the Fir-lice is confined to the preceding observations. No one has yet seen the copulation of these animals, nor has any one yet proved with certainty the existence of a male. It is a mere assumption that a copulation precedes the oviposition of the winged animals; and it is nothing more than an assumption when Ratzeburg (op. cit. p. 201) regards the smaller individuals of this winged generation as males, and considers the elongated form of their abdomen, and the presence of an obtuse penis-like organ (Ruthe) protrusible by pressure with the compressorium, as characteristic attributes of their sex. The same questions still remain to be answered with regard to the reproduction of the Fir-lice, that De Geer proposes at the end of his account of the natural history of these animals.

I am happy that my investigations enable me to give some more definite information upon the conditions in question. This, however, is not in favour of an opinion which not long since held the place of an irrefragable law, and which also influenced the earlier observers in their suppositions.

$I$ have convinced myself that the reproduction of our Fir-lice 
takes place in both generations by a parthenogenetic process, by the spontaneous development of the eggs.

Although I have examined fully two hundred of our animals, I have never met with a male among them. All the individuals, wingless and winged, large and small, were females, and, indeed, virgin females. This was the case not only with animals taken before oviposition, but also with those engaged in depositing their eggs, and even with those whose eggs already presented distinct traces of the commencement of evolution, or even contained developed embryos. More than once I isolated the eggs of such virgin animals, and afterwards saw them hatch.

After such observations, there can be no doubt that the Firlice generally propagate without males. But whether males are entirely wanting, or whether they merely make their appearance from time to time, under certain favourable circumstances, and then fecundate the females, I must leave undecided; yet it almost appears to me as if certain anatomical conditions, to which I shall have to refer hereafter, rendered the first supposition to a certain extent credible.

It is, however, not only the common Fir-louse (C. Abietis) that behaves in this manner. Towards the end of April I several times observed on the young shoots of the Fir a wingless Louse (C. Picea, Ratzeb. ?), which presented an extraordinary resemblance to the individuals of the first generation of $C$. Abietis, but was distinguished therefrom partly by its darker, almost black colour, and partly by its far smaller size. I can state nothing with regard to the mode of life of this species: I afterwards sought in vain upon the infected trees for galls, and must leave it undecided whether our animal, like $C$. Abietis, subsequently produces a second winged generation; this, however, is very probable. But I am certain that all the individuals examined, amongst which were several with eggs already deposited although not numerous, proved to be unfecundated females, exactly as in the corresponding state of $C$. Abietis.

I can assert the same thing of the nearly allied Phylloxera coccinea, Von Heyden, of which I met with numerous wingless females, at the commencement of July, on the lower surface of oak-leaves, with eggs deposited in rings. In this case, also, the older eggs (about 30-40 in number) contained an embryo already far advanced in development, although no trace of semen was to be detected in the mothers. Previous observers have overlooked the existence of this first generation of wingless females: they speak of winged animals which made their appearance in August and September, and fastened their eggs to the oak-leaves exactly in the same way as the wingless females. Unfortunately, I have not succeeded in finding these winged 
Phylloxere, but I have scarcely any doubt that they would have proved without exception to be female animals. From all analogy, these winged individuals are the progeny of the wingless forms observed by me, which, on their part, represent the first generation of Chermes, and will have passed the winter either as young animals, or, as their later appearance would almost lead us to believe, as eggs.

If the latter supposition be well founded, our Phylloxera would be distinguished thereby not only from Chermes Abietis*, but also from C. Laricis, which otherwise approaches it most closely in form and mode of life (residence on the surface of the leaves, and incapability of forming galls).

With regard to the conditions of reproduction, however, the same statements apply to the latter as to other species previously referred to. The Larch-louse also only exhibits the female sex in both wingless and winged individuals; it always consists, as far as I am aware, only of parthenogenetic virgins.

But with regard to the relation in which these two forms of individuals stand to each other, I have not been able to arrive at so clear a conclusion as in the case of $C$. Abietis. Nevertheless it almost appears as if $C$. Laricis behaved somewhat differently in this respect. According to the statements of Kaltenbach and Ratzeburg, there is indeed no doubt that the minute creatures which pass the winter on the still undeveloped buds are developed first of all only into wingless individuals; but it is equally certain that in this case the winged individuals make their appearance very early, and occur for a long time together with wingless females. I found such winged individuals as early as the end of May, a few weeks after the first eggs, which in this species are but few in number, were met with. Moreover, according to Ratzeburg's observations, the eggs of the first generation do not produce winged individuals exclusively, as in C. Abietis, but wingless forms are produced at the same time; the latter, however, are somewhat different from the original wingless animals, and produce a third generation in the same year. That the winged individuals lay eggs, like the wingless ones, was unknown to Ratzeburg; I have, however, convinced myself of this in the most certain manner, but must remark that the number of these eggs is less than that produced by the wingless females.

By the greater number of the consecutive generations, and also by the fact that these generations are represented, at least in part, simultaneously by winged and wingless individuals,

* It was by mistake that, in my memoir on the alternation of generations and Parthenogenesis in insects, I stated that the eggs of C. Abietis passed through the winter. 
Chermes Laricis evidently approaches the ordinary Aphides in its conditions of reproduction, except that the viviparous individuals, as also in Phylloxera, are replaced by egg-laying females, and that male individuals are entirely wanting (at least, as a general rule).

[To be continued.]

\section{XXXIV.-On some new Anthribida.}

By Francis P. Pascoe, F.L.S. \&c.

IN common with many other families of Coleoptera, the Anthribidæ have received very little attention from entomologists. This is, perhaps, partly owing to their being scattered in small numbers over every part of the world, and Europe possessing only about twenty of them out of the twelve hundred which our collections are calculated to contain. Of these, according to M. Jekel, who has specially studied the family, not more than two hundred are published; and there are consequently a number of new forms, only a few of which I have here attempted to describe, and these principally derived from Mr. Wallace's researches in the Indian Archipelago. Indeed the family may be considered to have its head-quarters in those islands : in all Mr. Wallace's collections, including those from New Guinea, they formed, from the number both of species and individuals, a very characteristic feature, and in this respect afforded a marked contrast to collections from extra-tropical Australia. It is probable, however, that we shall hereafter find the northern or tropical part of the Australian continent to assimilate more to the opposite shores of New Guinea, and that the very distinctly marked region extending from Java to the latter island will have Ceylon, and perhaps a portion of Southern India, on the one hand, with tropical Australia, and not New Guinea, on the other, as outlying or transition provinces.

As no attempt has yet been made to classify the family, which contains at least three distinct types of form, I have thought it best to avoid any remarks respecting the affinities or position of the new genera here proposed*. It is, perhaps, as well also to observe that the individuals of many Anthribidæ vary much more than is usual in regard to size, markings, and the relative proportion of their parts, . particularly of the rostrum and antennæ.

* In order to condense as much as possible, I have generally omitted all characters which belong to the Anthribidæ as a family; and even those here given may perhaps hereafter be curtailed without disadvantage. 


\section{$2 \mathrm{BHL}$ Biodiversity Heritage Library}

Leuckart, Rudolf. 1859. "XXXIII.-On the reproduction of the Bark-lice (Chermes, \&c.); a further contribution to the knowledge of Parthenogenesis." The Annals and magazine of natural history; zoology, botany, and geology 4, 321-327.

View This Item Online: https://www.biodiversitylibrary.org/item/19633

Permalink: https://www.biodiversitylibrary.org/partpdf/31475

\section{Holding Institution}

Natural History Museum Library, London

\section{Sponsored by}

Natural History Museum Library, London

\section{Copyright \& Reuse}

Copyright Status: Public domain. The BHL considers that this work is no longer under copyright protection.

This document was created from content at the Biodiversity Heritage Library, the world's largest open access digital library for biodiversity literature and archives. Visit BHL at https://www.biodiversitylibrary.org. 